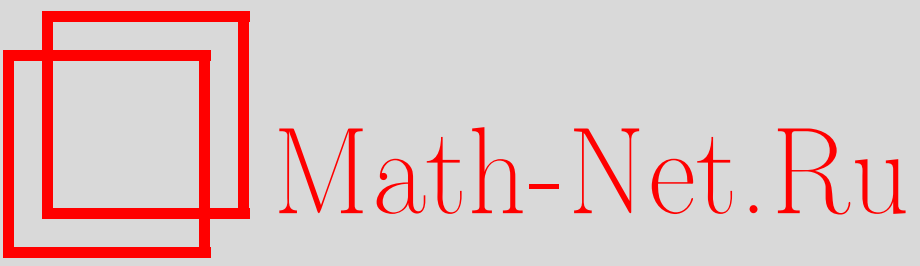

И. Ю. Цвелодуб, В. П. Радченко, Памяти Олега Васильевича Соснина, Вестн. Сам. гос. техн. ун-та. Сер. Физ.-мат. науки, 2009, выпуск 2(), 6-8

DOI: https://doi.org/10.14498/vsgtu734

Использование Общероссийского математического портала Math-Net.Ru подразумевает, что вы прочитали и согласны с пользовательским соглашением

http://www. mathnet.ru/rus/agreement

Параметры загрузки:

IP : 107.22 .136 .117

26 апреля 2023 г., 18:05:45 


\section{Памяти Олега Васильевича Соснина}

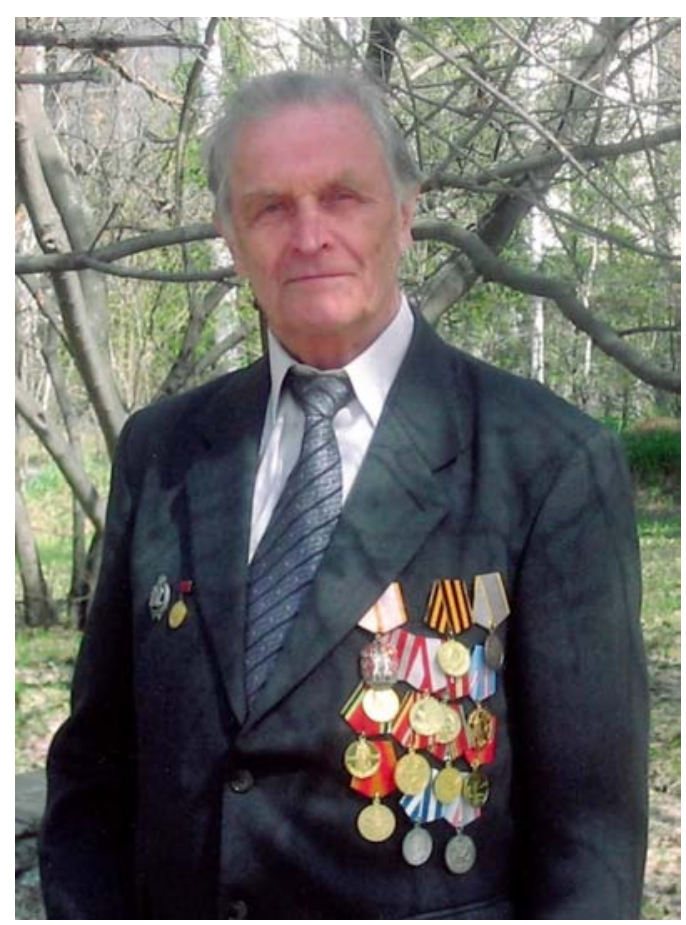

$(11.10 .1926-15.07 .2009)$

15 июля 2009 г. на 83-м году жизни нас покинул замечательный человек и учёный, известный специалист в области механики деформируемого твёрдого тела, доктор физико-математических наук профессор Олег Васильевич Соснин.

Научная деятельность Олега Васильевича началась в аспирантуре при Московском государственном университете.

В 1958 г. Олег Васильевич уезжает в Сибирь и продолжает научную деятельность в Институте гидродинамики СО АН СССР под руководством академика Ю. Н. Работнова, где и работал до конца жизни. В 1961 г. за разработку метода расчета напряжённо-деформированного состояния дисков турбомашин, материал которых находится в условиях неустановившейся ползучести, О. В. Соснину присуждена учёная степень кандидата технических наук.

Под его непосредственным руководством реализована программа экспериментальных исследований, связанных с изучением свойств анизотропии авиационных сплавов, обоснованием энергетического варианта теории ползучести и длительной прочности алюминиево-магниевых и титановых сплавов, изучением влияния вида напряженного состояния и истории нагружения на прочностные и деформационные свойства материалов в процессе их ползучести. Результаты этих исследований составили содержание его докторской диссертации «О ползучести металлических материалов», успешно защищенной в 1971 г. 
Итогом экспериментально-теоретических исследований в области ползучести и длительной прочности конструкционных материалов и элементов конструкций явилось то, что Олегу Васильевичу с соавторами из Института механики Московского государственного университета, Куйбышевского политехнического института (ныне Самарский государственный технический университет) и Всесоюзного института авиационных материалов (г. Москва) в 1990 г. присуждена Государственная премия РСФСР в области науки и техники за разработку и экспериментальное обоснование математической теории ползучести и её приложений.

Перечисленные выше результаты нашли непосредственное применение при экспериментально-теоретическом исследовании, связанном с формообразованием элементов конструкций в режимах ползучести и сверхпластичности, а также при решении задач проектирования и расчёта на прочность оптимальных по долговечности элементов конструкций. Многие результаты, полученные в области обработки материалов давлением в режимах ползучести и сверхпластичности, внедрены в ряде предприятий городов Улан-Удэ, Новосибирска, Кургана, Свердловска, Тбилиси, Омска.

Олег Васильевич подготовил более 20 кандидатов наук, постоянно работал с аспирантами, являлся научным консультантом по ряду докторских диссертаций, более 30 лет руководил лабораторией статической прочности, возглавлял отдел механики деформируемого твёрдого тела, являлся председателем совета по защите докторских диссертаций, принимал активное уча-

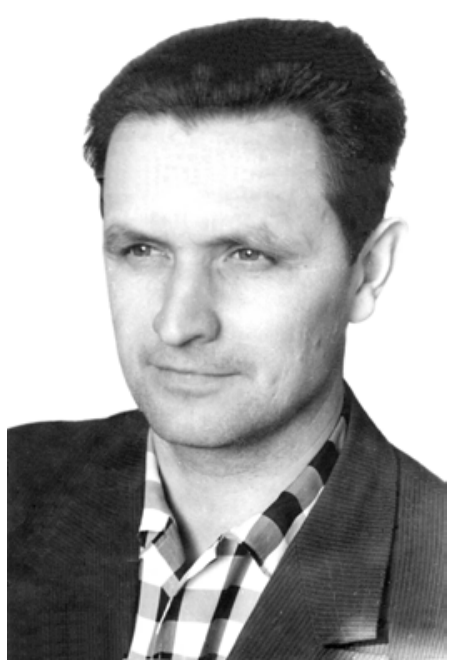

Годы молодые ...

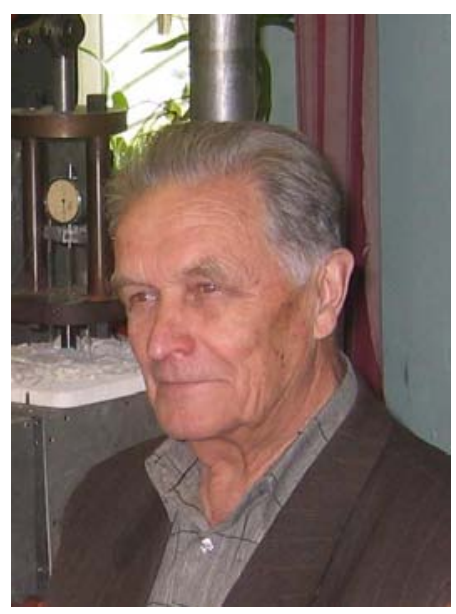

В родной лаборатории стие в работе диссертационных советов Новосибирска, Якутска, Томска, Бишкека, Чебоксар, Москвы.

Более 30 лет О.В. Соснин поддерживал научные контакты с Куйбышевской (Самарской) научной школой по механике деформируемого твёрдого тела, он входил в оргкомитет ежегодной Всероссийской научной конференции «Математическое моделирование и краевые задачи», являлся членом редакционного совета журнала «Вестник Самарского государственного технического университета. Серия: Физико-математические науки».

Олег Васильевич - один из лидеров ведущей научной школы России «Неупругое деформирование и разрушение неоднородных сред и конструкций», заслуженный деятель науки РФ. Научные школы ползучести и сверхпластичности, наряду с научными школами Москвы и Ленинграда (Санкт-Петербурга), оказали огромное влияние на формирование теории ползучести как в 
отечественной, так и в зарубежной науке.

Олег Васильевич много времени уделял научно-организационной работе. Он являлся первым учёным секретарем Института гидродинамики, в течение многих лет работал заместителем директора Института.

Будучи фронтовиком, участников Великой Отечественной войны, награждённым орденами и медалями, О. В. Соснин остро переживал распад Великой Страны в начале 90-х годов и всегда верил в Россию, её будущее и, в частности, в науку страны, которой посвятил всю свою жизнь. Он понимал цену преемственности поколений в научной сфере и всегда делал всё от него зависящее для привлечения молодёжи в академическую и вузовскую науку.

Учёный, Администратор, Преподаватель, Учитель, Человек, Патриот, ... . Не только власть авторитета и глубина знаний привлекала к нему людей. Работая с ним рядом, сотрудники с уважением относились к его требовательности, трудоспособности, порядочности, человечности, ценили в нём натуру умную и тонкую, хорошо знающую культуру и историю своей страны.

У Олега Васильевича было и остаётся много искренних почитателей его личности и таланта, обязанных ему своим становлением в науке и в жизни вообще.

Светлая память об Олеге Васильевиче Соснине навсегда сохранится в сердцах всех знавших его людей.

Цвелодуб И. Ю., д.ф.-м.н., профессор, зав. лабораторией статической
прочности ИГиЛ СО РАН;
Радченко В. П., д.ф.-м.н., профессор, зав. кафедрой прикладной математики и информатики СамГТУ. 